\title{
Conceptual principles of project management for development of hydrate and other unconventional gas fields as a component of energy security of Ukraine
}

\author{
Olha Ovetska ${ }^{1}$, Serhii Ovetskyi ${ }^{2}$, and Oleh Vytiaz ${ }^{2}$ \\ ${ }^{1}$ Ivano-Frankivsk National Technical University of Oil and Gas, Department of Management and \\ Administration, 1 Shopena St, 76000 Ivano-Frankivsk, Ukraine \\ ${ }^{2}$ Ivano-Frankivsk National Technical University of Oil and Gas, Institute of Petroleum Engineering, \\ 15 Karpatska St, 76019, Ivano-Frankivsk, Ukraine
}

\begin{abstract}
Topical issues concerning the possibilities of effective development of unconventional gas fields, in particular gas hydrate as an element of Ukraine's energy security, are covered. Attention is drawn to the need for an integrated approach to the development of unconventional hydrocarbon deposits using project management methods. The main challenges, opportunities, scenarios of energy security of Ukraine are studied. Priority tasks in the gas sector are analyzed in accordance with the implementation of the New Energy Strategy of Ukraine for the period up to 2035 at the stage "Optimization and innovative development of energy infrastructure (until 2025)" and "Ensuring sustainable development (until 2035)". Peculiarities of development of unconventional hydrocarbon deposits at each stage of management - discovery, evaluation, development, production and closure of the project are determined. The purpose of the article is a comprehensive substantiation of organizational and technological decisions to increase the efficiency of development of offshore gas hydrate fields in comparison with other unconventional gas fields.
\end{abstract}

\section{Introduction}

The strategic task in accordance with the New Energy Strategy of Ukraine for the period up to 2035 [1] provides for bringing the state to the level of maximum energy independence. At the same time, by 2025 the main focus should be energy saving, maintenance of the achieved volumes of hydrocarbon production and maximum diversification of primary energy supply. In particular, in the gas sector at the second stage "Optimization and innovative development of energy infrastructure (until 2025)" provides:

- creating conditions and stimulating the maintenance of the achieved levels and further increase of own production, in particular on new areas and on the continental shelf and within the exclusive (marine) economic zone of Ukraine;

*Corresponding author: oveckuj@gmail.com 
- promoting the expansion of opportunities to further improve the efficiency of existing capacities and the implementation of new infrastructure projects.

Among the priority tasks in the gas sector at the stage of "Ensuring sustainable development (until 2035)" - the successful implementation of projects for the development of natural gas fields, including from unconventionalsources [1]:

- investments in exploration and development of new gas and gas condensate fields, including on the continental shelf and within the exclusive (marine) economic zone of Ukraine;

- increase of national production at the expense of gas from unconventional hydrocarbon deposits to $30-35$ billion $\mathrm{m}^{3} /$ year;

- continued involvement of the world's leading companies for the development of the Black Sea shelf and the development of unconventional hydrocarbon deposits; etc.

The Black Sea countries have significant deposits of methane hydrates both in the national sectors of the Black Sea and in marine economic zones (48 trillion cubic meters according to the Institute of Oceanology of the Bulgarian Academy of Sciences [2]). According to the forecast volumes of unconventional gas, Ukraine is one of the 10 most promising countries in the world in terms of potential production opportunities - their total volume exceeds 20 trillion $\mathrm{m}^{3}$ (forecast shale gas resources are estimated at 1.2 trillion $\mathrm{m}^{3}$ ) [3].

In this context, Ukraine has every reason to develop both natural gas production, using its traditional reserves, in particular, on the shelf and the continental slope of the Black Sea, and the development of unconventional gas deposits, in particular, shale, which Ukraine does not have a leading position in the world, however, even according to preliminary estimates, has sufficient potential in terms of meeting its own needs. At the same time, the serious problems of the development of unconventional gas production will be the opposition of the monopoly external supplier, limited investment, lack of water resources and environmental aspects of the application of fracturing technologies [4]. Confirmation of reserves and identification of promising areas of shale gas requires large-scale exploration and geological works according to expert estimates in two areas: the Dnieper-Donetsk basin (Eastern Ukraine) and the Ukrainian part of the Lublin Depression (Western Ukraine). Thus, exploration and production of hydrocarbons, including unconventional ones, should become today priority areas for ensuring the energy independence of Ukraine in general, and the Western region in particular [5].

Thus, according to the results of a previous study by the authors [6], the overall prospects for energy security of Ukraine largely depend on the development of unconventional gas fields. In particular, the creation of regional programs to increase the resource base of alternative gas sources is closely related to the development of gas deposits in shale and tight rocks, which requires:

- accounting for existing and search for promising areas for the development of shale gas and gas of tight rocks;

- involvement of leading higher education institutions in the formation of a program for the development of such fields in order to study existing technologies and improve them taking into account regional conditions;

- development of modern tools for project management for the development of unconventional gas fields.

The phased implementation of the tasks of the New Energy Strategy of Ukraine "Security, Energy Efficiency, Competitiveness" in the context of the implementation of the Sustainable Development Strategy until 2030 [7], will require the implementation of appropriate large-scale investment projects and programs. Taking into account the main features of the project activity in the development of gas hydrate fields, the modern methodology of project management allowed to identify several main features of project identification of the project concept development phase, in particular $[8,9]$ : 
- in terms of implementation - long-term, more than 3 years (the second and third stages of reforming the energy sector - "Optimization and innovative development of energy infrastructure" (until 2025) and "Ensuring sustainable development" (until 2035));

- in scale - large;

- in terms of complexity - complex and very complex megaprojects as complex infrastructure projects for the development of the gas sector of the economy, consisting of mono- and multi-projects and today require professional multi-project management based on modern methodology of project-oriented management.

\section{Description of features of management of development of unconventional gas fields}

All deposits, both traditional and unconventional, go through a life cycle, from exploration to discovery and, finally, to the completion and elimination of wells (Fig. 1) [10]. The overall life cycle consists of the exploration phase, development based on drilling and production in different phases, namely: primary, secondary and tertiary. Each subsequent stage of the life cycle of field development changes the influence of different specialists, according to the skills required to manage field development.

5. Abandonment (removing of surface equipment and plagging the well)

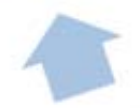

4. Production (gas extraction)

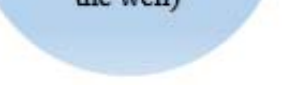

1. Exploration (searching for the gas deposits)
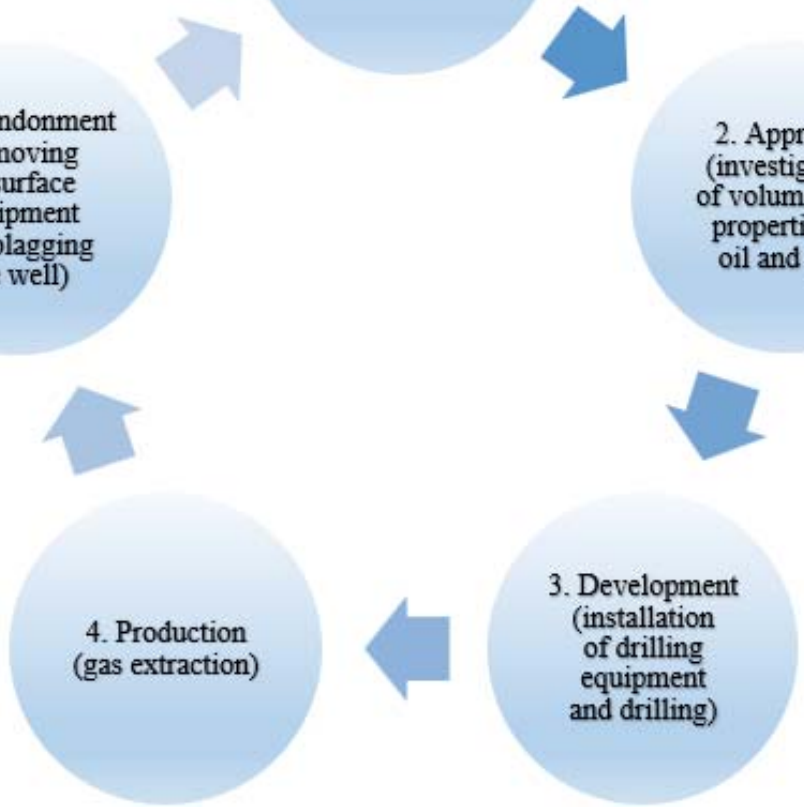

Fig. 1. Life cycle of an oil and gas field.

A well-thought-out process that needs to be planned, implemented, monitored and tested for the results obtained is the key to effective management of field development. Constantly, during the life of the field development project, corrective measures are taken. Commercially 
effective development management can be carried out for many decades, using various innovative, currently, technologies, throughout the life of the field. To obtain a time-efficient process of field development, it is necessary to conduct a high-quality pre-investment phase, the scheme of which is presented in Fig. 2. The first option pre-investment phase (Fig. 2a [11]) is an overview of the responsibilities of the engineering and technical group of reservoir resources to manage the development of shale gas fields, and the second option (Fig. 2b) is predictive for the development of gas hydrate fields.

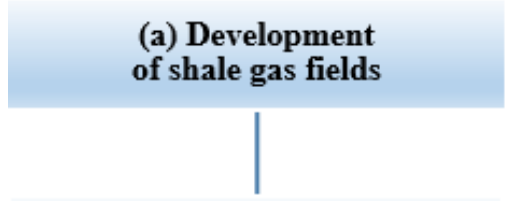

Gather petrophysical, geological, geochemical, and hydraulic fracture characteristics. Evaluate reservoir data for existence of natural fractures

Investigation of wells to determine the properties of the reservoire filtration characteristics of the collector and composition of fluid

Design and perform technology of hydraulic fracture characteristics and well design

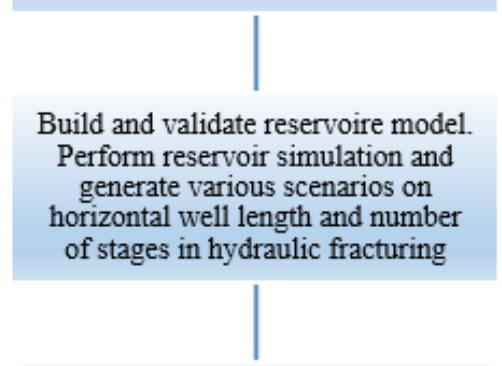

Forecast production and perform economic analysis on best case, worst case, and most likely scenarios

Prepare a field development plan

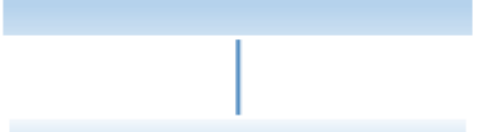

(b) Development of hydrate deposits

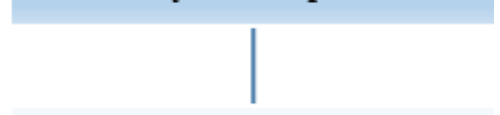

Gather petrophysical, geological, geochemical, and hydraulic fracture characteristics. Evaluate reservoir data for existence of natural fractures

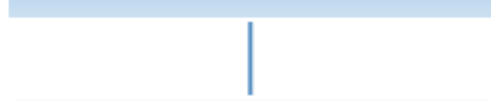

Investigation of wells to determine the properties of the reservoire filtration characteristics and composition of the hydrate

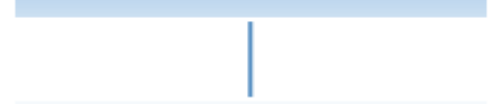

Design and perform technology of development of hydrate deposits and well design and (or) gas collection and preparation systems

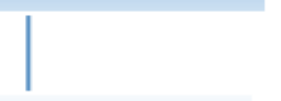

Perform reservoir simulation and generate various scenarios taking into account the features of bottom and sub-bottoms hydrates

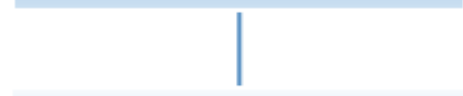

Forecast production and perform economic analysis on best case, worst case, and most likely scenarios

Prepare a field development plan

Fig. 2. The list of works of the pre-investment phase in the development of: (a) shale gas fields; (b) gas hydrate fields. 
The life cycle of unconventional gas fields can differ significantly from both traditional and from each other. For example, the construction of a shale deposit development model involves the inclusion in the work primarily of parts of the deposits with better filtration characteristics and higher methane content - "sweet spots" [12]. A characteristic feature of the development of hydrate deposits are significant differences in the development of deposits of different localization - terrestrial provide mainly the method of depressurization and temperature exposure [13]; for oceanic deposits - the method of substitution [14], bottom the temperature effect using the energy of bottom mud volcanoes [15]. Among Ukraine's energy security, only marine gas hydrate deposits [16], shale gas deposits, and, to some extent, methane from coal seams can be important, so the main focus on managing the development of unconventional gas fields is focused on them.

\section{Results and discussion}

According to Fig. 1, consider the typical life cycle of unconventional deposits, highlighting the features of each type important for energy security of Ukraine, which are mentioned above.

1. Discovery of the field. To replenish energy reserves, Ukraine's geological industry is constantly looking for new oil and gas fields, including unconventional ones. These include Oleska Square (shale gas), Yuzivska Square (tight rock gas), geological and industrial areas of Donbass (coalbed methane) and oil and gas areas of the north-western part of the Black Sea (gas hydrate deposits).

The shift in the focus of offshore oil and gas development from coastal to mediumdepth and deep-water areas, with the use of new technologies such as horizontal offshore drilling and floating platforms, allows for the development of gas hydrate deposits [9]. Among the technological achievements of recent years, technologies of multi-stage fracturing come to the fore, which allow to effectively develop gas deposits in shale and tight rocks. Geologists and geophysicists participate in exploration and contribute to the description of traditional deposits, determining the depth, structure, stratigraphy, disturbance of geological structure, size, system of aquifers and location of potential deposits. For unconventional deposits, geochemical and geomechanical studies are also important. Determine:

- for shale and tight reservoirs - the possibility and efficiency of hydraulic fracturing, its technological parameters;

- for methane deposits of coal seams - duration and cost-effective period of downhole gas production;

- for gas hydrate deposits - the possibility of using technologies for removal of hydrates from thermodynamic equilibrium.

Successful development of oil and gas fields is associated with the first stage of the life cycle of their development, namely the geological study of existing deposits in the field, which is characterized by the level of maturity and saturation of organic matter, the presence of migration routes from parent rock to trap, filtration properties permeability), the presence of gas and oil and water oil contact. In this case, the minimization of risks of obtaining "dry" wells during development is determined by the presence and degree of study of the above components. However, unconventional gas deposits are characterized by the absence of such elements as migration routes and the presence of a trap with a classical structure, as coal deposits, shale deposits and hydrate accumulations are parent rocks.

2. Estimation of the field. Potential reserves of traditional and unconventional deposits, as well as possible production methods, are estimated on the basis of limited geological information, using petrophysical surveys, geophysical surveys during drilling and modeling of reservoirs. The accuracy of assessing the prospects of the field is quite high. 
Due to certain features, unconventional deposits may be further easier to find and estimate reserves. Due to the large area of shale, tight and hydrated gas fields, new wells are likely to reach their targets. It remains to find the most attractive for mining parts of the deposits with high potential productivity. In addition, marine gas hydrate deposits are often associated with the presence of underwater mud volcanoes, which are a reliable sign of the presence and prospects of bottom and bottom gas deposits.

Evaluate the location of productive formations with the thickness of the reservoir, porosity, gas saturation, gas and oil contact, reservoir pressure and probable performance indicators geologists, drilling engineers and development engineers. Determines whether to drill additional wells, including appraisal wells, which leads to clarification of the size and properties of deposits. Despite the obvious increase in the cost of the project, such actions may reveal future geological problems that will not hinder its overall implementation, as unconventional field is usually located in a complex geological environment, including stratification, faults, faults, barriers, and anisotropy porosity and permeability.

Again, additional data are collected on the characteristics of the reservoir, such aschanges in reservoir thickness, porosity, gas saturation and reservoir pressure. For unconventional deposits, the core is taken from several wells, which are analyzed in the laboratory for porosity, absolute permeability, relative permeability and spectrographic characteristics. The properties of gas and water are determined by analyzing the formation fluid samples. For compacted and shale gas deposits it is especially important to accurately determine the filtration properties of the rock and its strength characteristics, and for marine hydrate deposits - the type of hydrate and rock saturation with hydrates.

3. Development of the field. The development of an unconventional field begins with drilling an economically feasible number of wells and the distance between them. The use of horizontal drilling, as a rule, in this situation allows you to minimize costs. The location of wells is based on a multivariate process of modeling the development of the field with the definition of the optimal strategy [17]. Shale and tight gas-bearing rocks due to low permeability required a large number of vertical wells, but the advent of horizontal drilling technology and the use of hydraulic fracturing allowed to significantly reduce their number. Gas hydrate fields will also be developed using horizontal wells [14], but their number can be minimized using substitution gas production technology. The technology of production from bottom gas hydrate deposits requires drilling of inclined wells of large diameter, but small length [18], to stabilize the flow of emissions from underwater volcanoes and increase methane production.

As Ukraine's promising gas hydrate fields are at sea, it should be borne in mind that their development will require additional capital costs for drilling and production using floating drilling rigs (semi-submersible drilling rigs or drilling vessels), production (FPSO or TLP platforms, submarines). gas storage and transportation equipment at sea. Borehole drilling of horizontal wells is most often used to minimize costs, which allows drilling and operating a large number of them from a single drilling and production platform. Thus, in terms of capital investment, this is the most costly phase of the life cycle of gas hydrate development.

4. Production. Usually production begins with a small number of wells, the rest are drilled during development, which are determined by the stages of production: primary, secondary and intensified. The primary stage of gas production is carried out due to the energy of the natural formation. An example of the use of the primary stage of production can be the production of gas by depressurization (pressure reduction), which leads to the dissociation of the hydrate and increase the gas pressure [13]. For marine gas hydrate deposits, the use of this method of production does not result in an economically justified volume of gas and can cause environmental problems of various kinds [19]. 
Secondary stage of production, which is characterized by an artificial increase in reservoir energy by introducing a liquid or gas. For gas hydrate, shale, tight rocks, as well as coalbed methane, the secondary stage of development is usually impossible due to chemical bonds with the parent rock, high adhesion strength and low permeability of these deposits.

Gas supply intensification processes include thermal, chemical and mixed effects on the productive horizon. For gas-bearing shale and tight rocks, the main method of both development and intensification of the inflow is hydraulic fracturing, which, forming a network of artificial cracks, allows to obtain the inflow of gas into the well [20]. For coal deposits in the presence of previous downhole gas production, subsequent shaft operation with methane production in various ways can be assessed as a tertiary method of operation. For marine gas hydrate fields, hydraulic fracturing can be used as a tidal intensification process [21], but their development and control of the gas production process are associated with temperature exposure to bottom hydrates (eg, using the energy of underwater mud volcanoes [15]) or a chemical process. replacement by another hydrate-forming gas, in particular carbon dioxide or hydrogen sulfide, for deep bottom deposits [14].

5. Refusal of further development. Further gas production from traditional and unconventional fields is abandoned when it is impossible to obtain a break-even point to maintain the field's productivity. The minimum productivity of wells, the location of the field on land or sea, operating costs, market conditions, environmental and other standards and other factors can play a crucial role in abandoning further development. Common reasons for refusal include [11]:

- reduction of oil and gas production rates, which are not economically sustainable;

- low gas content in the extracted fluid;

- costs for intensification of gas inflow do not exceed the income from sales;

- the cost of operation and maintenance of the field is excessive at an unfavorable rate of return on investment.

Restoration of work on abandoned shale gas and tight gas fields is not underway, as the only method of obtaining a third of the extra volume may be hydraulic fracturing, already used for their development. The accumulation of methane in abandoned coal mines indicates the possibility of their recovery as sources of additional methane.

Other features of the development of unconventional deposits are related to several stages, which will be considered separately, as the maximization of profits from the field is possible only with constant consideration of technical, technological, economic and legal aspects. The field development management process should be continuous at all five stages (Fig. 1), which correspond to the generally accepted stages of project management that have led to the success of many international companies: initiation, planning (Fig. 2), implementation, quality monitoring and control and project closure.

Every management process has various components, including time management, budget management, quality management, communications management, integration management, risk management, area management and human resource management.

The internal management environment for gas production projects from unconventional fields is described above, but we should not forget about the external environment, namely the components:

- corporate - purpose, financial capacity, culture and attitude;

- economic - business climate, gas prices and inflation;

- social - norms of preservation, safety and environmental protection.

The field management process can be described as integrated, dynamic and continuous [11].

The development of gas hydrate fields requires greater focus on certain areas of field management, as it is characterized by the use of technologies that have not yet been tested substitution or thermal effects, lack of detailed information on the characteristics of hydrate-bottom, bottom or deep, unpredictable efficiency of horizontal and slope 
investment in marine equipment and greater risks, which are also more associated with a hostile environment. Other unconventional deposits have their own features of development management: shale and tight require the use of a large number of wells and multi-stage hydraulic fracturing, and mine methane deposits - the involvement of various types of expensive equipment for multi-stage development using well and mine technologies.

Since the cost of gas production of unconventional fields is always higher than that of traditional ones, and is on the verge of profitability of development, the issue of estimating production indicators is especially important. However, methods for estimating reserves and future production volumes for gas hydrate, as well as some other unconventional gas fields, are underdeveloped. Existing methods used in the development of traditional gas fields, such asvaluation of reserves, forecasting the productivity of wells, classical material balance, analysis of the pressure drop curve, simulation of the reservoir and production processes require their adaptation to the needs of unconventional gas fields.

Environmental issues can play a crucial role in the development of offshore gas hydrate fields [19]. However, using the technology of replacing methane in deep bottom hydrates with carbon dioxide or hydrogen sulfide, using the energy of volcanic gases to dissociate bottom hydrates in methane production, you can get their "greening" and the corresponding additional environmental effect [21]. A clear example of the use of sustainable development principles can also be observed in the extraction of coalbed methane, because harmful greenhouse gas methane is not released into the atmosphere, but is used as fuel. When developing shale and tight gas fields, it is necessary to keep in mind the regulatory restrictions on hydraulic fracturing, which allow to make this process environmentally and technologically safe.

\section{Conclusions}

The use of unconventional gas fields, in particular gas hydrate, can be a crucial component of Ukraine's energy security. To do this, it is necessary not only to improve production methods, but also to develop a strategy for the development of deposits of unconventional hydrocarbons, in particular gas hydrates. For this type of field, certain features of the development management process are outlined, the main ones being: methods of development of resources of unconventional gas fields, such as chemical substitution of methane for deep bottom hydrates, or thermal impact on bottom hydrate deposits, often used in secondary or tertiary production stages. traditional deposits; the risks associated with managing the development of unconventional natural gas fields arise mainly due to high capital investments in high-value equipment, such as semi-submerged platforms and underwater pipelines for offshore gas hydrate fields; when implementing the latest methods of developing unconventional gas fields, it is necessary to take into account the possibility of obtaining an ecological effect through "landscaping" of technologies such as replacing methane in the hydrate lattice with carbon dioxide or capturing emissions from underwater volcanoes to use their energy to dissociate bottom hydrate deposits.

The current level of methods of gas production from unconventional fields cannot exceed $30 \%$ of reserves for shale deposits and deposits of tight rocks, and for gas hydrate deposits $-45 \%$. This is due to the fact that the methods of the secondary and tertiary stages of development in the first case and the secondary stage in the second case have not been developed yet.

This work was carried out within the projects "Development of methods and technologies for gas production from natural gas hydrates and creation of artificial gas hydrates to optimize production processes" (State registration \#0113U000789c) and "Study of natural gas hydrate formation and development of gas hydrate field development technologies" (State registration \#0115U002281). 


\section{References}

1. Enerhetychna stratehiya Ukrayiny na period do 2035 roku "Bezpeka, enerhoefektymnist, konkurentospromozhnist". (2017). Rozporyadzhennya Kabinetu Ministriv Ukrayiny 18 serpnya 2017 roku No. 605-r. http://www.kmu.gov.ua/control/uk/cardnpd?docid=250250456

2. Dimitrov, L., \& Vassilev, A. (2002). Black Sea methane hydrates - haw many are they? BulgarianI nstitute of Oceanology. GASHYDAT (MAS3-CT98-0176 Project). http://www.iobas.bg/crimea/Partners/Publications/BSGH HowManyAre.pdf

3. Analitychna dopovid Tsentru Razumkova. (2011). Alternatyvne hazozabezpechennya Ukrayiny: skraplenyy pryrodnyy haz ta netradytsiynyy haz. Natsionalna Bezpeka i Oborona, (9), 25-43.

4. Enerhetychna bezpeka Ukrayiny do 2020 roku: vyklyky, mozhlyvosti ta stsenariyi. (2011). Kyiv, Ukraina: Ukrayinskyy instytut publichnoyi polityky.

5. Ovetska, O.V. (2018). Stratehichni perspektyvy rozvytku Ivano-Frankivskoi oblasti yak skladovoi enerhetychnoi bezpeky Ukrainy. Innovatsii Maibutnoho, 29-31. USA, Morrisville, Lulu Press.

6. Ovetska, O.V., \& Oveckiy, S.O. (2018). Vykorystannia potentsialu vydobuvannia netradytsiinoho hazu yak priorytetnyi napriam rozvytku pidpryiemstv palyvno-enerhetychnoho kompleksu IvanoFrankivskoi oblasti. Hazohidraty ta Inshi Alternatyvni Dzherela Hazu, 81-85. Ivano-Frankivsk, Ukraina: Lizunoff Press.

7. Natsionalna dopovid "Stratehiia staloho rozvytku Ukrainy do 2030 roku”. (2017). Kyiv, Ukraina: Ministerstvo ekonomichnoho rozvytku i torhivli Ukrainy.

8. Ovetska, O.V., \& Oveckiy, S.O. (2018). Stratehichni peredumovy reformuvannia kompanii PEK Ukrainy na zasadakh suchasnoi metodolohii proekt-oriientovanoho upravlinnia. In Materialy mizhnarodnoi naukovo-praktychnoi konferentsii "Nauka ta osvita: klyuchovi pytannia suchasnosti”, (7), 110-112. Chernihiv, Ukraina: Yevropeiska naukova platforma.

9. Koltun, P., \& Klymenko, V. (2016). Methane hydrates - Australian perspective. Mining of Mineral Deposits, 10(4), 11-18. https://doi.org/10.15407/mining10.04.011

10. Paulauskiene, T. (2018). Petroleum extraction engineering. Recent Insights in Petroleum Science and Engineering. https://doi.org/10.5772/intechopen.70360

11. Abdus Satter, \& Ghulam M. Iqbal. (2016). Reservoir engineering. The Fundamentals, Simulation, and Management of Conventional and Unconventional Recoveries. Editor(s): Abdus Satter, Ghulam M. Iqbal, Gulf Professional Publishing, (472 p.), The Boulevard, Langford Lane, Kidlington, Oxford. https://doi.org/10.1016/B978-0-12-800219-3.00007-3

12. Evans, M.J. (2016). Unconventional hydrocarbons and the US technology revolution. Risks, Rewards and Regulation of Unconventional Gas: A Global Perspective, 59-91. https://doi.org/10.1017/9781316341209.006

13. Moridis, G.J., Collett, T.S., Boswell, R., Kurihara, M., \& Reagan, M.T. (2008). Toward production from gas hydrates: Assessment of resources, technology and potential. Society of Petroleum EngineersOnePetro. https://doi.org/10.2118/114163-MS

14. Oveckiy, S., \& Savchuk, V. (2016). A method developed to increase technological and ecological efficiency of gas production from hydrate deposits. Eastern-European Journal of Enterprise Technologies, 3(81), 41-47. https://doi.org/10.15587/1729-4061.2016.72545

15. Klymenko, V.V., Vytyaz, O.Yu., \& Oveckyi, S.O. (2016). Pro metod vydobuvannia metanu z donnykh hazohidratnykh pokladiv z vykorystanniam vykydiv pidvodnykh vulkaniv. In Materily II Mizhnarodnoyi naukovo-tekhnichnoyi konferentsiyi "Hazohidratni tekhnolohiyi u hirnytstvi, naftohazoviy spravi, heotekhnitsi ta enerhetytsi”, 8-9.

16. Žuk, G.V., P'âtničko, O.I., Krušnevič, V.T., Fedorenko, D.S., \& Klimenko, V.V. (2016). Methane hydrate technologies in Ukraine - research and prospects. AGH Drilling, Oil, Gas, 33(4), 811-818. https://doi.org/10.7494/drill.2016.33.4.811

17. Emami Niri, M., \& Lumley, D. (2016). Probabilistic reservoir-property modeling jointly constrained by 3D-seismic data and hydraulic-unit analysis. Society of Petroleum EngineersOnePetro. https://doi:10.2118/171444-PA 
18. Oveckyi, S.O. (2020). Zahalni pryntsypy pidhotovky hrezovykh vulkaniv do rozrobky donnykh hidratnykh pokladiv. Perspektyvni Napryamky Naukovykh Doslidzhen, 57-60.

19. Zyrin, V., \& Ilinova A. (2018). Gas hydrates production in the Arctic Zone: Ecological aspects. International Journal of Applied Engineering Research, 13(1), 606-611.

20. Zeng, F., Cheng, X., Guo, J., Tao, L., \& Chen, Z. (2017). Hybridising human judgment, AHP, grey theory, and fuzzy expert systems for candidate well selection in fractured reservoirs. Energies, 10(4), 447. https://doi.org/10.3390/en10040447

21. Oveckiy, S.O. (2019). Outlook "greening" of hydraulic fracking technology for the production of unconventional hydrocarbons. MNPK "Problèmes et Perspectives D'introduction de la Recherche Scientifique Innovante”, 89-90. https://doi.org/10.36074/29.11.2019.v2 